DOI 10.17805/zpu.2018.4.14

\title{
Статья А. П. Сумарокова «О несогласии» в апрельской книжке журнала «Трудолюбивая Пчела»: текст и контекст*
}

\author{
А. В. РАСТЯГАЕВ, Ю. В. СЛОЖЕНИКИНА
}

МОСКОВСКИЙ ГОРОДСКОЙ ПЕДАГОГИЧЕСКИЙ УНИВЕРСИТЕТ, САМАРСКИЙ ФИЛИАЛ

В статье исследуется семантическое ядро апрельского номера журнала «Трудолюбивая Пчела» - эссе А. П. Сумарокова «О несогласии». Актуальность проблемы исследования определяется тем, что журнал в целом и каждая помесячная его книжка в отдельности практически не попадают в сферу исследовательского внимания историков литературы и журналистики. Предложенная методология исследования основана на принципе синергии нескольких направлений современной филологической науки: истории русской литературы XVIII в., истории отечественной журналистики, истории русского литературного языка. Данный подход к анализу, интерпретации и пониманию журнального метатекста призван воссоздать целостную картину взаимодействия авторской интенции и читательского восприятия.

В статье исследуется смысл заглавия «О несогласии» как сильной позиции текста, реализующей интенцию автора на диалог с читателем-современником. Предпринимается попытка восстановления культурного контекста данного словоупотребления в произведениях Феофана Прокоповича, Петра І, В. К. Тредиаковского и М. В. Ломоносова. Слово «несогласие» в письменных текстах XVIII в. актуализировалось в различных значениях. Однако только у Сумарокова оно вынесено в заглавие и помимо коммуникативной выполняет еще и смыслообразующую функцию.

Анализ композиции риторического сюжета эссе Сумарокова выявил основной принцип его построения - следование «простоте естества». Заявленный во вступлении тезис об истинных причинах несогласия между людьми - «несходство сердец» - объяснительно аргументируется тремя примерами различной тематики: любовной, имущественной и бытовой. Далее авторская мысль следует от простого к сложному и переходит на уровень обобщения в контексте всемирной истории.

Интерпретация поэтологического сюжета статьи последовательно воссоздает ее древнеримский и позднеантичный культурные контексты, также выявляет рецепцию традиции раннего английского Просвещения.

Исследование текста и контекста одной статьи апрельской книжки журнала позволяет сделать вывод о том, что журнал Сумарокова - не только новая эпоха в развитии российской журналистики, но и новое слово в поэтике и герменевтике, которые в середине XVIII в. усилиями авторов «Трудолюбивой Пчелы» приходят на смену риторике.

Ключевые слова: «Трудолюбивая Пчела»; А. П. Сумароков; М. В. Ломоносов; риторика; поэтика; Гораций; Овидий; Псевдо-Лонгин; Аддисон; Стил; русская литература XVIII в.; история литературы

\section{ВВЕАЕНИЕ}

\К урнал «Трудолюбивая Пчела» (далее - ТП) издавался А. П. Сумароковым ежемесячно с января по декабрь 1759 г. и был закрыт по причинам не до конца понятным. 12 книжек журнала стали принципиально новым для XVIII в. типом периодического издания в России, которое печаталось по частной инициативе Сумарокова и распространялось по подписке.

* Исследование выполнено при финансовой поддержке РФФИ в рамках научного проекта № 18-012-00356 А «Журнал А. П. Сумарокова “Трудолюбивая Пчела" (1759) и его значение для русской литературы XVIII века».

The study was financially supported by the Russian Foundation for Basic Research. The research project No 18-012-00356 A. The magazine of A. Sumarokov "Hardworking Bee" (1759) and its significance for Russian literature of XVIII century. 
Репертуар большинства номеров ТП представляет собой сочетание текстов различной жанровой природы. Это переводные и оригинальные произведения в прозе и в стихах, тексты древних и новых авторов, труды самого Сумарокова и его коллегсочувственников. Кажущаяся эклектичность ТП долгое время мешала историкам литературы отойти от тематической и жанровой описательной методологии при обращении к текстам сумароковского издания и увидеть определенную логику отбора материала для каждого номера журнала. В помесячных книжках ТП создавалось специфическое метатекстовое единство, утверждавшее особую философию жизни, которая опиралась на тысячелетнюю культурную традицию.

Однако в истории литературы XVIII в. сложилась устойчивая традиция интерпретации текстов сумароковских статей исключительно в связи с полемическими высказываниями автора против риторической программы М. В. Аомоносова. Подобная позиция не всегда учитывает более глубокий культурный контекст сумароковских текстов, а зачастую именно он и порождает смысл отдельной публикации. Такова, на наш взгляд, и природа статьи Сумарокова «О несогласии», опубликованной в апрельском номере ТП 1759 г.

\section{СМЫСА ЗАГААВИЯ СТАТЬИ «О НЕСОГААСИИ»: \\ УСТАНОВКА НА АИАИОГ С ЧИТАТЕАЕМ}

В апрельской книжке ТП Сумароков впервые публикует несколько статей собственного сочинения, которые не перемежаются с переводами, произведениями других авторов, а следуют одна за другой. Это три работы без жанрового обозначения: «О несогласии» (Трудолюбивая Пчела, 1759: 231-235), «О разности между пылким и острым разумом» (там же: 235-237), «О неестественности» (там же: 237-240). Все вместе они образуют особое метатекстовое единство, мини-цикл в пределах апрельской книжки.

Первая статья цикла озаглавлена Сумароковым «О несогласии». Вступление начинается со слов: «Несогласие в роде человеческом не столько от разности степеней разума, сколько от несходства сердец происходит» (там же: 240) и заканчивается: «Что два и два суть четыре, все разумы в том согласны; а что разбирают сердца?, в том сего согласия нет» (там же). При явном отсутствии свойственной Сумарокову живописной конкретики и сценической образности автору все же удается создать драматическое напряжение другими средствами. Это прежде всего особое словоупотребление, контрастные маркеры, на которых строится весь риторический сюжет статьи. Это, по сути, всего две пары слов: «несогласие / согласие» и «разум / сердце». Причем первые два мастерски закольцовываются уже в первой микротеме и сохраняют свою антонимичность до конца, вторые же подвергаются философскому осмыслению, и их кажущаяся очевидной противоположность оспаривается. Почему же в заглавие статьи Сумароков выносит именно слово «несогласие»- что затемняет смысл статьи и заставляет читателя находить дополнительные коды, изучать культурный контекст для интерпретации такого короткого текста?

Ю. М. Цотман в примечании к статье «Семиотика культуры и понятие текста» замечает: «Заглавие может относиться к обозначаемому им тексту по принципу метафоры или метонимии. Оно может быть реализовано с помощью слов первичного языка, переведенных в ранг метатекста, или с помощью слов метаязыка и т. А. В результате между заглавием и обозначаемым им текстом возникают сложные смысловые токи, порождающие новое сообщение» (Иотман, 2002b: 161). Подобные «сложные смысловые токи» переводят «простой» на первый взгляд текст статьи Сумарокова на мета- 
текстовый уровень, порождая новое сообщение. Чтобы разобраться в механизме этого перевода, обратимся к слову «несогласие», обозначенному в заглавии.

В словаре В. И. Ааля зафиксировано четыре значения слова «несогласие»: «ср. противопол. согласие, во всех знач. разногласие (голос, мненье), противность мнения, разность убеждений, разномыслие; || разногласие (голос, звук), как нестройность в голосах или звуках музыкальных, разлад, дисгармония; || споры, ссоры, вражда, раздор, несовет; || разноречие, разнословие, устное или на бумаге, напр. между двумя стихами подлинника, в показании подсудимого и пр.» (Ааль, 1995b: 535)

Старославянский словарь фиксирует только по одному значению наречия «согласно» - «единодушно, в один голос, единогласно»; и прилагательного «согласен»«единодушный, согласный» (Старославянский словарь ..., 1999: 646).

Судить о значении слова «несогласие» в XVIII в. возможно только по данным Национального корпуса русского языка, поскольку последний по времени том (21-й) Словаря русского языка XVIII века его не включает (Словарь русского языка XVIII века, 2015). Аанное слово зафиксировано корпусом с начала XVIII столетия в текстах Феофана Прокоповича, Петра I, В. К. Тредиаковского и М. В. Аомоносова и др. У Феофана Прокоповича в «Слове похвальном о баталии Полтавской» (1717) находим: «Известно любопытным естеств взыскателем есть, что магнит камень силу свою, которою влеком есть к железу, окормляет, силою железа себе обложеннаго. Тако воистинну и зависть кормится и растет чуждым благополучием, себе близким; в том только не ревность, что магнит таковым способом идет в болший союз, а зависть в болшую вражду зажигается. А яко же обычно есть мечты и копии острые, сковавше противными стихами, жаром и мокротою закаливати, тако недруги наши завистную свою на нас ярость закрепили, видяще у себе и у нас в законе и в державе, во обычаях несогласие, инный вид правителства, противное исповедание, разные обряды. Что все аще и бывает инде с неповреждением дружбы, однако ж где зависть, там все тое есть оной укрепительная материя(курсив наш. - А. Р., Ю. С.)» (Прокопович, 1961: 51-52). Аругими словами, зависть рождает вражду как следствие несогласия, т. е. разности, разноречия в обычаях, государственном устройстве, вероисповедовании и $m$. $n$.

В тексте «Регламента или устава главного магистрата», подписанном Петром I (1721), в главе XV «O спорных делах между магистратами и гражданами» слово «несогласие» употреблено в другом значении: «Ежели где у граждан с магистратами в чем учинится какой спор и несогласие» (Регламент ..., 1937: 199), т. е. несогласие спорьи, ссорьь, вражда, раздор.

В. К. Тредиаковский в «Слове о мудрости, благоразумии и добродетели (1752) замечает: «Рассуждение сие есть или самозрительное, или умствовательное. Первым наш ум двух понятий сходство или несходство без посредства третиего понятия тотчас познает... Но вторым познавает ум двух понятий сходство или несогласие чрез посредство третиего или и многих понятий» (Тредиаковский, 2009: 286). 3десь Тредиаковский сам определяет значение слова «несогласие»- несходство, при этом вводит его уже в философский дискурс, а не в пропагандистский, как у Прокоповича, или юридический, как у Петра I.

Тексты, наиболее близкие хронологически к 1759 г., где употреблено слово «несогласие» принадлежат перу М. В. Аомоносова. Первый текст - письмо от 1 ноября 1753 г. И. И. Шувалову: «Советник Шумахер, пренебрегая то, что он от его сиятельства г. президента присланным ордером о произведении публичного акта изобличен был в своих неправедных поступках в рассуждении моей речи, употребил еще все ко- 
варные свои происки для ее остановки. Правда, что он всегда был высоких наук, а следовательно и мой ненавистник и всех профессоров гонитель и коварный и злохитростный приводчик в несогласие и враждование, однако ныне стал еще вдвое, имея двойные интересы, то есть прегордого невежду, высокомысленного фарисея, зятя своего Тауберта» (Иомоносов, 1957: 495). Здесь несогласие - сnорь, ссоры, вражда (враждование), раздор.

Второй текст - «Слово похвальное блаженныя памяти Государю Императору Петру Великому, говоренное апреля 26 дня 1755 года» (1755): «Правда, что первое под Нарвою сражение было неудачливо, но противных преимущество и Российскаго воинства уступление к их прославлению и к нашему уничтожению больше от зависти и гордости увеличены, нежели каковы были самою вещию, ибо, хотя Российское войско было по большей части двулетное против стараго и к сражениям приобыкшаго, хотя несогласие учинилось между нашими полководцами и злохитрой переметчик открыл неприятелю все обстоятельства нашего стана...» (Иомоносов, 1959: 595). Здесь несогласие - противность мнения, разность убеждений, разномыслие.

Можно сделать вывод, что слово «несогласие»в письменных текстах XVIII в. употреблялось в различных значениях, наиболее близких к толкованиям словаря В. И. Ааля. Однако только у Сумарокова слово «несогласие» вынесено в заглавие, а сам тест строится на игре смыслов, т. е. помимо коммуникативной функции «выполняет и смыслообразующую, выступая уже не в качестве пассивной упаковки заранее данного смысла, а как генератор смыслов» (Иотман, 2002а: 189).

В каком значении Сумароков употребляет данное слово в заглавии, какой смысл приобретает оно в сильной позиции текста? Ответить на этот вопрос можно, приняв тезисы Ю. М. Аотмана об общении между текстом и культурным контекстом, поскольку сам текст статьи Сумарокова данный вопрос не проясняет. По мысли ученого, «отношения текста к культурному контексту могут иметь метафорический характер, когда текст воспринимается как заместитель всего контекста, которому он в определенном отношении эквивалентен, или же метонимический, когда текст представляет контекст как некоторая часть - целое» (Иотман, 2002b: 161).

Частью какого целого является статья «О несогласии», какие уровни сложного культурного контекста она представляет?

\section{КОМПОЗИЦИЯ РИТОРИЧЕСКОГО СЮЖЕТА}

Сам текст статьи построен достаточно просто, его композиция вполне естественна и понятна. Во вступлении заявленный главный тезис: «Несогласие в роде человеческом не столько от разности степеней разума, сколько от несходства сердец происходит» (Трудолюбивая Пчела, 1759: 231) поясняется целым рядом умозаключений.

Во-первых, причина несогласия между людьми в том, что «люди больше сердцем, нежели разумом от истины отходят» (там же).

Во-вторых, даже умный человек не в силах противостоять порочному сердцу: «Вкорененное в сердце зло редко разумом преодолевается» (там же: 231-232). Более того, даже образованный человек способен намеренно искажать правила, законы и научные истины в угоду торжества собственного мнения: «Поврежденные сердца неправедные предписывают нам законы, пристрастные производят умствования, безстыдные подают нам предприятия и к дерзновенным приводят нас исполнениям» (там же: 232).

В-третьих, даже разумный человек, став на ложный путь, к истинному уже не вернется и останется навсегда в плену собственной несостоятельной точки зрения, 
так как «неправедные мнения так мало с истиной, как мало сами между собою соглашаются» (там же). Именно в этом автор статьи видит корень всех разногласий и ссор, «основание несогласия и безпокойства всемирного» (там же). По его мнению, не отсутствие разума как такового мешает людям жить в согласии, а исключительно сердечное несогласие или слепотствующий разум, поскольку «самолюбие ослепляет человека, и всему тому противоречит, чево мы в склонности сердца своего не находим» (там же).

Завершает вступление фраза: «Что два и два суть четыре, все разумы в том согласны; а что разбирают сердца?, в том сего согласия нет» (там же). С одной стороны, она закольцовывает все высказанные сентенции и отсылает к началу статьи, в том числе и к заглавию, с другой - дает возможность продолжить развитие сюжета и перейти к аргументам, уже конкретным примерам.

Аалее, без деления на абзацы, следуют примеры-аргументы, однако они или предельно абстрактные, или гипотетические, правда, не лишенные объяснительной доказательности.

Первый пример связан с темой любви, где сердечное несогласие представляется наиболее очевидным, как-то: «Одна женщина одному прекрасна, а другому посредственна кажется» (там же) и т. п. Второй касается вопроса имущественного: «Сын проигрывает имение отца своего, не внимая угрожений отцовых...», «Скупой любит деньги, сын его - излишнее щегольство; между родителем и сыном несогласие» (там же: 233). Наконец, третий пример на первый взгляд из разряда очевидных: «Трезвый и пьяный не составляют беседы» (там же). Но далее автор, множа примеры, выходит на иной уровень обобщения: «Ученый с невежею хотя и действительно часто от разума не соглашаются, однако невежи нередко к ученым прилепляются, имея в сердцах склонность понимать доброе, от них научаются и разум на высшую степень возводят (там же). И делается вывод: поскольку «несогласие, происходящее от разума, часто преодолеваемо бывает, а происходящее от сердца редко», то «все споры, все брани и непримиримая вражда от разности сердец происходят» (там же).

Последний ряд примеров ориентирован на всемирную историю и приобретает вневременной размах. Сердечное несогласие настолько сильно в людях испокон веков, что «сам прехвальный Христианский закон мерзкой вражды из сердец злодейских выгнать не может» (там же: 234). Напротив, «ежели бы у всех людей сердца были честны, и разумы просвещены, и все бы люди в добродетели геройствовали; не было бы ни участных, ни народных браней» (там же).

В качестве примеров антигероев Сумароков называет имена Катилины и Александра Великого: «Катилина не восстал бы против вольности своего отечества. Александр не зашел бы в отдаленную Индию, умерщвлять безвинных человеков» (там же). Автор не подвергает сомнению бесчеловечность деяний античных героев, ставя между ними знак равенства: «И того и другого разум довольно уверял о том, что они безчеловечные предприятия имеют» (там же). Однако общественная оценка их деятельности кардинально противоположная: «Катилине не было удачи сделать безчеловечие; Александру удалось» (там же). Только поэтому, считает Сумароков, «первый извергом естества почитается, а второй - великим Героем» (там же). Причем «первому дала сие титло истина, второму - лесть» (там же).

Заканчивается статья Сумарокова двумя риторическими вопросами. На первый автор отвечает сам: «Но люди, установляющие несогласие, должны ли называться Героями, хотя бы всю вселенную покорили? Однако они за то, что вводят несогласие, лав- 
рами венчаются» (там же). На второй: «Не стыдно ли сие роду человеческому?» (там же) - предлагает ответить читателю.

Налицо установка автора на общение читателя-современника с текстом, напечатанным в апрельской книжке ТП. При әтом сам текст «становится равноправным собеседником, обладающим высокой степенью автономности» и выступает «как самостоятельное интеллектуальное образование, играющее активную и независимую роль в диалоге» (Иотман, 2002b: 161). Однако при перемещении текста из одного культурного контекста в другой он «актуализирует прежде скрытые аспекты своей кодирующей системы», «становится значительнее самого себя и приобретает черты модели культуры» (там же).

Попытаемся проследить обе данные тенденции, присущие тексту Сумарокова и выходящие далеко за рамки классической риторики.

\section{ОСОБЕННОСТИ ПОЭТОАОГИЧЕСКОГО СЮЖЕТА:}

\section{АНТИЧНЫЙ КУАБТУРНЫЙ КОНТЕКСТ}

А. Е. Махов в экскурсе «Concordia discors» приводит специфические для Античности, Средневековья и Нового времени литературные термины-топосы, которые выражали эстетическую оценку произведения (Махов, 2010: 324-327).

Средневековая формула concordia (symphonia) discors или discordia concors, которая переводится с латинского как согласие несогласного, несогласное согласие, стала топосом для «выражения определенного поэтологического идеала» (там же: 324). Генетически этот средневековый топос восходит к древнеримской поэзии, которая дает возможность двоякой оценки. Так, у Горация в «Послании к Пизонам» (данная работа более известна как «Об искусстве поэзии» De ars poetica) впервые встречается формула symphonia discors:

$$
\begin{aligned}
& \text { ut gratas inter mensas symphonia discors } \\
& 375 \text { et crassum unguentum et Sardo cum melle papaver } \\
& \text { offendunt, poterat duci quia cena sine istis } \\
& \text { sic animis natum inventumque poema iuvandis, } \\
& \text { si paulum summo decessit, vergit ad imum. }
\end{aligned}
$$

(Horatius ... : Электронный ресурс).

Первым текст «Послания к Пизонам» перевел прозой и опубликовал с примечаниями в 1752 г. В. К. Тредиаковский: «Равно как на великолепном пировании несогласная мусикия, нечистое умащение и Сардинский горький мед с маком досаждают, для того что стол и без сих неприятностей мог отправиться, так для пользы и сладости рожденная и изобретенная поэма ежели хотя мало не достигнет до высоты, то на самый низ стремглав упадает» (Тредиаковский, 2009: 64). Соответственно symphonia discors переводится как несогласная мусикия.

В 1753 г. спустя три месяца поле выхода перевода Тредиаковского Н. Н. Поповский печатает свой стихотворный перевод:

Но должен ли же я всегда в надежде той

Писать как хочется, по воле все слепой?

Нет, должно рассуждать, что будут все пороки

Усмотрены во мне и примут суд жестокий.

И, хоть бы знал, что мне простят мою вину,

Однак не допускать, чтоб быть обличену 
Н. Ю. Алексеева предполагает, что «инициатором соревнования с Тредиаковским в переводе поэтики Горация был, по-видимому, Аомоносов, в то время наставник Поповского в стихосложении» (Алексеева, 2009: 537). Однако ни ученик, ни учитель, который, вероятно, принимал деятельное участие в работе над переводом, не преуспели в передаче формы и содержания оригинала. Поскольку «Поповский ориентировался на немецкий перевод поэтики Горация, выполненный И. Хр. Готшедом», его текст «повторяет синтаксическую организацию стихотворной речи Готшеда» (Алексеева, 2006: 31), а не Горация. В столь вольном переложении труда Горация трудно даже соотнести строки русского перевода с латинскими, хотя нумерация и дается, но при этом полностью меняется не только синтаксическое членение стихотворной речи Горация, но и подменяется весь лексический состав, в котором опознать значимые античные топосы или эстетические формулы невозможно.

Второй прозаический перевод «De ars poetica» сделал A. И. Хвостов в 1813 г., у него symphonia discors - нескладная музыка: «Как во время приятной беседы нескладная музыка, тяжелые курения и мак с сардинским медом оскорбляют утонченное чувство, тем более что удовольствия стола можно бы продолжить было и без сих прихотей; так точно и поэма, самою природою назначенная для увеселения духа, если хотя мало не приближается к высшей степени своего назначения, непременно падает и сопровождается презрением» (Гораций, 1813: 46).

В более поздних стихотворных переводах М. А. Амитриева, А. А. Фета и М. А. Гаспарова symphonia discors соответственно - нестройной симфонии звуки, симфония в полном разладе и нескладный напев:

Как за приятным обедом нестройной симфонии звуки,

Запах грубых мастик, мак, смешанный с медом сардинским,

Всем досаждают затем, что обед и без них обошелся б:

Так и поэзия, быв рождена к наслаждению духа,

Чуть с совершенства сойдет, упадает на низкую степень!

(Гораций, 1853: 56).

Как за приятной трапезой симфония в полном разладе,

Мак на Сардинском меду и старый елей безуханный

Только бесят, затем, что без них бы мог ужин продлиться.

Так и стихи, сочиненные с целью доставить приятность,

Чуть не дошли до высокого, в низкое тотчас впадают

(Гораций, 1883: 478).

Как на богатом пиру нескладный напев музыкантов, Мак в сардинском меду иль масло, жирное слишком, Нам претят, ибо мы и без них пировали бы славно, Точно так и стихи, услада душевная наша, От совершенства на шаг отступив, бездарными будут

(Гораций, 1970: 392).

И тест оригинала, и приведенные варианты русского перевода подчеркивают, что у Горация явленная им формула symphonia discors несет «отчетливую негативную коннотацию: она обозначает нестройную музыку, с которой сравниваются посредственные стихи малоодаренного поэта» (Махов, 2010: 324).

Подобной негативной коннотации discors concordia нет уже у Овидия в «Метаморфозах»: 
quippe ubi temperiem sumpsere umorque calorque, concipiunt, et ab his oriuntur cuncta duobus, cumque sit ignis aquae pugnax, vapor umidus omnes res creat, et discors concordia fetibus apta est

(Ovidii : Электронный ресурс).

В русском переводе А. А. Фета discors concordia - это мирный раздор:

Ибо когда с теплотой как должно смешается влага,

То зарождают они, и от двух этих все происходит.

Как сразится с водою огонь, то из влажного пара

Все создается и в мирном раздоре зародышам любо

(XV книг Превращений, 1887: 31).

У С. В. Шервинского - несогласье согласное:

Ибо, коль сырость и жар меж собою смешаются в меру,

Плод зачинают, и все от этих двоих происходит.

Если ж в боренье огонь и вода, жар влажный, возникнув,

Все создает: для плодов несогласье согласное в пользу

(Овидий, 1977: 42).

Напротив, в «Метаморфозах» из discors concordia, двух противоположностей, рождается жизнь и ее дальнейшая гармония.

Средневековые музыковедческие и поэтологические тексты адаптирует античную формулу discors concordia именно с положительной эстетической оценкой. Более того, в средневековой литературе возникает жанр спора, в котором доминантой становится идея несогласия, диссонанса, противоречия, в основе которой топос discordia. B XVII в. прежде всего в барочной словесности формула discors concordia получает распространение в качестве и поэтического топоса, и поэтологического принципа. Мироощущению барокко свойственна фиксация контрастов и антитез, диссонансов, разладов и разногласий, которым отдается приоритет в силу их первичности по отношению к последующей гармонии. Классицизм XVIII в. оценивает топос concordia discors резко негативно как часть поэтики барокко (Махов, 2010: 324-327).

Неслучайно русские переводчики XVIII в. Тредиаковский и Поповский воспринимают именно горацианскую, негативную оценку данной формулы, а Тредиаковский публикует перевод «Послания к Пизонам» под одной обложкой с «Поэтическим искусством» Буало.

В статье Сумарокова «О несогласии» аллюзивно присутствует concordia discors, причем формула намеренно усекается автором до (symphonia) discors - несогласия. Однако само ее присутствие в культурном контексте дает короткому тексту дополнительную способность порождения нового смысла. Причем имя Буало и переводческий труд французского мыслителя, по сути, предваряют собственные тексты Сумарокова. Речь идет об отрывке «Из трактата Аонгинова, о важности слова с перевода Боалова (Глава II.)» в переводе Сумарокова этого же апрельского номера ТП (Трудолюбивая Пчела, 1759: 233).

\section{ПОЗАНЕАНТИЧНЫЙ КУАБТУРНЫЙ КОНТЕКСТ: TРАКТАТ «О ВОЗВЫШЕННОМ »}

Если имя Буало играет роль знака, отсылающего читателя одновременно и к французскому тексту «Поэтического искусства» (или его русскому переводу Тредиаков- 
ского, опубликованному в 1752 г.), и эпистоле «О стихотворстве» Сумарокова 1748 г.,

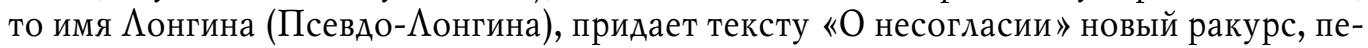
реводя его в иной культурный контекст.

Теоретико-литературный трактат «О возвышенном» был написан в первой половине I в. н. э. Ао нашего времени позднеантичный текст дошел в поврежденном виде: нет титульного листа и недостает трети рукописи. Его первоначальная неверная атрибуция была обусловлена ошибкой в датировке. Авторство в разное время приписывалось Плутарху, Аионисию Аонгину, Кассию Аонгину, Аионисию Галикарнасскому и др. На протяжении длительного времени считалось, что автором трактата был именно Аионисий Аонгин, а время создания текста - III в. н. э. Однако позже было доподлинно установлено, что сочинение было написано не позже I в. н. э., следовательно, Аионисий Аонгин его автором быть не может. Оказалось, что авторство установить невозможно. Тем не менее в научной среде было принято нейтральное определение

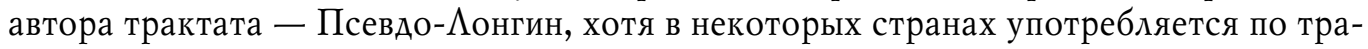
диции прежнее - Аонгин (Ажепароский, 2006: Электронный ресурс).

B России XVIII в. позднеантичный трактат «О возвышенном» впервые приобрел известность благодаря имени Буало и его вольному переводу данного текста. Известно, что М. В. Аомоносов конспектировал его не позднее второй половины 1738 г. Текст конспекта на французском языке сохранился и был опубликован в 2002 г. И. 3. Серманом (Серман, 2002: 333-346). Изданная Иомоносовым в 1757 г. статья «О пользе книг церьковных в Российском языке», в которой прослеживается вдияние трактата «О возвышенном», вероятно, и стала одним из поводов обращения Сумарокова к французскому переводу первоисточника. Издатель ТП сам перевел значимый для него отрывок с французского и напечатал его в апрельской книжке журнала, предварив им мини-цикл из трех статей собственного сочинения (Трудолюбивая Пчела, 1759: 219-224).

Трактат «О возвышенном» был открыт на закате Ренессанса, однако переписчики и переводчики XV-XVI вв. считали текст одним из вариантов риторики и не видели в нем поэтики (Чистякова, 1966: 113). Произведение Псевдо-Ионгина приобрело статус поэтологического архетекста только после публикации вольного перевода Буало в 1674 г. и его же исследования 1694 г. «Критические размышления по поводу некоторых мест у ритора Аонгина». Контекст острой полемики с Ш. Перро, вошедший в историю культуры как «Спор древних и новых», придал трактату «О возвышенном» особый вес, сделал авторитетным текстом, а его автора, минуя Средневековье, одним из основателей поэтики Нового времени.

По мысли Н. Т. Пахсарьян, интерес Буало к категории возвышенного был значительно глубже и не исчерпывался поиском аргументов против позиции Ш. Перро. В комментариях к трактату Псевдо- $о$ онгина, «"1e sublime” понимается не просто как характеристика стиля, но шире и глубже: “Возвышенный стиль требует значительных слов, но возвышенное может содержаться в самой мысли, в самом выражении, в обороте речи. Вещь, высказанная в возвышенном стиле, может не являться возвышенной, т. е. не содержать ничего необыкновенного или удивительного” (Пахсарьян, 2010: 185).

В обращении Сумарокова к трактату «О возвышенном» в переводе Буало Г. А. Гуковский усмотрел желание русского переводчика найти дополнительный аргумент в споре с Аомоносовым. Как в свое время сделал Буало в полемике с Перро, Сумароков публикует перевод с перевода «из трактата Аонгина “О высоком"... выбирая именно то место, в котором осуждаются "надутость", стремление “превзойти вели- 
кость”, “всегда сказать нечто чрезвычайное и сияющее”, осуждается “жар не во время”, излишняя “фигурность” речи, метафоризм и т. А. во имя “естественности”» (Гуковский, 1941: 374).

А. М. Песков развивает мысль Гуковского, считая одним из важных аспектов полемики Сумарокова с Аомоносовым именно категорию возвышенного. Ученый считает, что в трактате «О возвышенном» русского переводчика привлекла «интерпретация проблемы таланта и искусства», а публикация в ТП «полемически направлена против Аомоносова», поэтическое творчество которого критиковалось «за игнорирование правил искусства» (Песков, 1989: 28-29).

Аействительно, на первый взгляд расхожее место из сумароковского текста: «Трезвый и пьяный не составляют беседы» (Трудолюбивая Пчела, 1759: 233) - отсылает к трактату «О возвышенном». У Псевдо-Аонгина находим: «Некоторые авторы, подобно пьяницам, упиваются пафосом, не имеющим никакого отношения к содержанию их речи» (О возвышенном, 1966: 100). Однако далее автор указывает на причину подобного речевого поведения оратора: «К подобным излишествам влекут их личные склонности и безоговорочная вера в школьные правила» (там же). Таким образом, Сумароков критикует Цомоносова не за нарушение правил, а, напротив, за излишнее следование им, когда риторика входит в несогласие с поэтикой, когда ритору изменяет чувство, а поэту - вкус.

На наш взгляд, все три статьи Сумарокова направлены против риторичности ломоносовского стихотворства. В 1759 г. В. К. Тредиаковский - союзник издателя ТП, поэтому в одной статье критиковать Тредиаковского «за то, что тот сочиняет, не имея поэтического таланта, только по правилам», а в другой «Цомоносова, наоборот, за игнорирование правил искусства» Сумароков не мог (Песков, 1989: 29).

\section{КУАЬТУРНЫЙ КОНТЕКСТ РАННЕГО АНГАИЙСКОГО ПРОСВЕЩЕНИЯ:}

ЖУРНАА Р. СТИАА И АЖ. АААИСОНА «СМОТРИТЕАЬ»

Еще один культурный контекст статьи Сумарокова «О несогласии» - просветительская деятельность и журналистская практика Аж. Аддисона и Р. Стила, прежде всего их статьи в журнале «Смотритель» («The Spectator»). В апрельской книжке ТП трем оригинальным статьям Сумарокова непосредственно предшествует еще один перевод - «Части III. Из I. Речи Смотрителя» (Трудолюбивая Пчела, 1759: 229-231) также Сумарокова, но без указания языка посредника.

Всего в ТП в течение года были напечатаны четыре статьи из «Смотрителя», переведенные с французского. Впервые был опубликован перевод № 139, который до этого переводился дважды - Тредиаковским и анонимным переводчиком. Сумароков переводит и публикует только небольшой отрывок, в котором Р. Стил говорит о достоинствах Петра I, а критика французского короля усекается. По мысли Ю. А. Аевина, как и предшественники, Сумароков «помышлял не только о прославлении Петра, но и о назидании его наследникам» (Иевин, 1967: 35). В. А. Рак также уверен, что «в елизаветинской России тех лет выставление Петра в качестве образцового правителя приобретало учительный и вместе с ним антиправительственный смысл» (Рак, 2008: 127).

В предыдущем, мартовском номере ТП уже был напечатан материал из «Смотрителя» - «Речь XVIII из вторыя части Смотрителя» в переводе И. А. Амитревского. Это эссе Аддисона уже было опубликовано в «Примечаниях», но Сумароков «счел нужным повторить его, ибо его привлекало рационалистическое обоснование вечной 
жизни» (Аевин, 1967: 36). Безусловно, в 1759 г. Сумароков находился под сильным влиянием Аддисона, взглядов раннего английского Просвещения на искусство, которые складывались во многом благодаря знакомству с трактатом «О возвышенном».

В журнале «Смотритель» Аж. Аддисон публикует цикл из 11 статей под общим названием «Удовольствия воображения». В них английский журналист в качестве аргументов приводит цитаты из Псевдо-Аонгина. Вслед за позднеантичным автором Аддисон утверждает, что сила воображения, величие души способствуют возвышенным мыслям, рождению высокого. Причем «возвышенное» - это не риторический прием или высокий стиль, а категория поэтики. Более того, стремление к возвышенному заложено в самой природе человека (см.: О возвышенном, 1966: 6, 15, 64).

Аддисон связывает причину несогласия во вкусах со способностью или неспособностью к воображению: «Аолжно быть, это различие во вкусах вытекает либо из того, что совершенство воображения у одного больше, чем у другого, либо из того, что разные читатели присоединяют к одним и тем же словам разные идеи»1. Поэтому «поэт должен с таким же старанием обогащать свое воображение, с каким философ развивает свой ум». Будучи издателем журнала, который ратует за «изгнание порока и невежества из пределов Великобритании», Аддисон еще и стремился «установить вкус к изящной литературе» (Цурганова, 2010: 299-301).

Несомненно влияние Аддисона и на жанровую доминанту статей Сумарокова в ТП. В раннепросветительский период (1702-1714) литература в Англии стремилась выйти за рамки нормативности. Жанр эссе не был канонизирован классицистической поэтикой. Аддисон, как правило, не стремился давать конкретное жанровое определение своим произведениям, называя их то «обозрениями», то «письмами». Сумароков вообще не давал своим статьям в ТП жанровые определения вплоть до мая 1759 г., когда появляется серия статей под рубрикой «Письма» с впервые введенной римской нумерацией от I до IV - I. «O красоте природы» (Трудолюбивая Пчела, 1759: 312-314), II. «О больших беседах» (там же: 314-316), III. «О гордости» (там же: 316-318), IV. «О скорости и медленности» (там же: 318-320). Жанровое определение этих статей впервые перейдет и в оглавление номера под цифрой XVII. Письма (там же: 320).

\section{ЗАКАЮЧЕНИЕ}

Если за Стилом и Аддисоном прочно закрепилось реноме «эссеистов», их журналы толковались исключительно с социально-исторических позиций, то журнал Сумарокова ТП долго считался изданием одного автора, а его содержание якобы исчерпывалось исключительно сатирической направленностью. Е. А. Цурганова, исследовав поэтологическое содержание четырех томов «Болтуна», восьми томов «Зрителя» и трех томов «Опекуна» в их единстве и цельности, сделала вывод о том, что Аддисон и Стил открыли «новую эпоху в развитии английской и - шире - европейской журналистики» (Цурганова, 2008: 173). Сумароков, как издатель собственного журнала, безусловно, последователь Аддисона и Стила, а содержание его ТП не исчерпывается сиюминутной памфлетно-публицистической составляющей.

Исследование текста только одной статьи апрельской книжки ТП, помещенного в широкий европейский контекст, позволяет сделать вывод о том, что журнал Сумарокова - не только новая эпоха в развитии российской журналистики, но и новое слово в поэтике и герменевтике, которые в середине XVIII в. усилиями авторов журнала приходят на смену риторике. 


\section{ПРИМЕЧАНИЕ}

1 Тексты Аддисона цитируются в переводе Е. А. Цургановой.

\section{СПИСОК АИТЕРАТУРЫ}

XV книг Превращений (1887) / [Соч.] Публия Овидия Назона; В пер. и с объясн. А. Фета. М. : Тип. А. И. Мамонтова и К․ 793 с.

Алексеева, Н. Ю. (2006) Аитературная полемика середины XVIII века о переводе стихов // XVIII век : сб. ст. и мат. Т. 24 / отв. ред. Н. А. Кочеткова. СПб. : Наука, 410 с. С. 15-34.

Алексеева, Н. Ю. (2009) Комментарии // Тредиаковский В. К. Сочинения и переводы как стихами, так и прозою / подгот. Н. Ю. Алексеева. СПб. : Наука. 667 с. С. 501-654.

Гораций, Флакк (1753) Письмо Горация Флакка о стихотворстве к Пизонам / переведено с лат. яз. Николаем Поповским. СПб. : Печ. при Имп. Акад. наук, 40 с.

Гораций, Флакк (1813) Наука стихотворства Горация // Буало-Аепрео Никола. Наука стихотворства в четырех песнях стихами. Сочинение г. Буало-Аепрео. Перевод графа Хвостова. Издание второе, с приложением Горациева к Пизонам послания в подлиннике и с российским прозаическим оного переводом. СПб. : В Морской типографии, [6], VIII, 80, 53, [3] с. С. 1-53 (паг. 3-я).

Гораций, Флакк (1853) Наука поэзии, или Послание к Пизонам: С прил. подлинника, введ. и примеч., служащими к объясн. ориг. и пер. / [Соч.] Квинт Гораций Флакк ; пер. в стихах М. Амитриева. М. : Тип. А. Семена, VIII, 90 с.

Гораций, Флакк (1883) О поэтическом искусстве. К Пизонам // К. Гораций Флакк / пер. и с объясн. А. Фета. М. : Тип. М. П. Щепкина, XVIII, 485 с. С. 445-485.

Гораций, Флакк (1970) К Пизонам/ пер. с лат. / вступ. ст. и коммент. М. $\Lambda$. Гаспарова // Гораций. Оды, Эподы, Сатиры, Послания. М. : Художественная литература. 479 с. С. 383-395.

Гуковский, Г. А. (1941) Сумароков и его литературно-общественное окружение // История русской литературы : в 10 т. / гл. ред.: П. И. Аебедев-Полянский. М. ; $\Lambda$. : ИзА-во АН СССР. T. III. Аитература XVIII века. Ч. 1 / Редкол. тома: Г. А. Гуковский, В. А. Аесницкий. 424 с. C. 349-420.

Ааль, В. И. (1995а) Толковый словарь живого великорусского языка : в 4 т. М. : ТЕРРА. Т. 2: И-O. 779 c.

Ааль, В. И. (1995b) Толковый словарь живого великорусского языка : в 4 т. М. : ТЕРРА. Т. 4: $\mathrm{P}-\mathrm{V} .683 \mathrm{c}$.

Ажепароский, И. (2006) Первый архетекст о возвышенном: Псевдо-Ионгин [Электронный peсурс]// Филологические заметки. № 1. URL: http://philologicalstudies.org/index.php?option= com_content\&task=view\&id=86\&Itemid=48 (дата обращения 20.05.2018).

$\bar{\Lambda}$ евин, Ю. А. (1967) Английская просветительская журналистика в русской литературе XVIII века // Эпоха Просвещения. Из истории международных связей / отв. ред. академик М. П. Алексеев. $\Lambda$. : Наука. 364 с. С. 3-109.

Иомоносов, М. В. (1957) Письмо Шувалову И. И., 1 ноября 1753 г. // Иомоносов, М. В. Полное собрание сочинений. М. ; $\Lambda$. : [б. и.]. Т. 10: Служебные документы и письма. 1734-1765 гг./ ред. А. И. Андреев и ар. 934 с. С. 495-497.

Аомоносов, М. В. (1959) Слово Похвальное блаженныя памяти Государю Императору Петру Великому, говоренное Апреля 26 дня 1755 года // Аомоносов, М. В. Полное собрание сочинений. М. ; А. : [б. и.]. Т. 8: Поэзия; Ораторская проза; Надписи. 1732-1764 гг. / подгот. Г. П. Блоком, В. Н. Макеевой; примеч. Г. П. Блока и др.; ред. В. В. Виноградов и др. 1279 с. С. 584-612.

Иотман, Ю. М. (2002а) К современному понятию текста // Иотман, Ю. М. История и типология русской культуры. СПб. : Искусство-СПб. 768 с. С. $188-190$.

Иотман, Ю. М. (2002b) Семиотика культуры и понятие текста // Иотман, Ю. М. История и типология русской культуры. СПб. : Искусство-СПб. 768 с. С. 158-162.

Махов, А. Е. (2010) Concordia discors // Европейская поэтика от античности до эпохи Просвещения: Энциклопедический путеводитель / под общ. ред. Е. А. Цургановой и А. Е. Махова. M. : Intrada. 512 c. C. 324-327. 
О возвышенном (1966) / пер., статьи и примеч. Н. А. Чистяковой. М. ; А. : Наука. 158 с.

Овидий Назон, П. (1977) Метаморфозы / пер. с лат. С. В. Шервинского. М. : Художественная литература. 430 с.

Пахсарьян, Н. Т. (2010) Французская поэтика // Европейская поэтика от античности до эпохи Просвещения: Энциклопедический путеводитель / под общ. ред. Е. А. Цургановой и А. Е. Махова. М. : Intrada. 512 с. С. $178-192$.

Песков, А. М. (1989) Буало в русской литературе XVIII - первой трети XIX в. М. : ИзА-во МГУ. 176 с.

Прокопович, Феофан (1717) Слово похвальное о баталии Полтавской: Сказанное... через честнейшего отца, ректора Прокоповича, июня в 27 день 1717 // Феофан (Прокопович). Сочинения : под ред. И. П. Еремина. М. ; А. : Изд-во Акад. наук СССР. 1961.502 с. С. 48-59.

Рак, В. А. (2008) Статьи о литературе VIII века. СПб. : Пушкинский дом. 640 с.

Регламент или устав главного магистрата (1937) // Реформы Петра І. Сборник документов / сост. В. И. Аебедев. М. : Гос. соц.-эк. изд.-во. 376 с. С. 187-206.

Серман, И. 3. (2002) Неизданный конспект М. В. Аомоносова «Трактата о возвышенном» Псевдо-Ионгина в переводе Н. Буало // XVIII век : сб. ст. и мат. Т. 22/ отв. ред. Н. А. Кочеткова. СПб. : Наука. 457 с. С. 333-346.

Словарь русского языка XVIII века (2015) / ред. А. А. Алексеев. СПб. : Наука. Вып. 21. Подоба - Помощный. 238 с.

Старославянский словарь (по рукописям X-XI веков) (1999) / под ред. Р. М. Цейтлин, Р. Вечерки и Э. Благовой. М. : Русский язык. 842 с.

Тредиаковский, В. К. (2009) Сочинения и переводы как стихами, так и прозою / подгот. Н. Ю. Алексеева. СПб. : Наука. 667 с.

Трудолюбивая пчела (1759). В Санктпетербурге : [Тип. Акад. наук]. CK XVIII. T.4, 245 с.

Цурганова, Е. А. (2008) Преодоление жанровых границ в литературе раннего английского просвещения (журналы Аж. Аддисона и Р. Стила «Болтун», «Зритель», «Опекун») // Иитературоведческий журнал. № 23. С. 170-195.

Цурганова, Е. А. (2010) Английская поэтика. Раннее Просвещение // Европейская поэтика от античности до эпохи Просвещения: Энциклопедический путеводитель / под общ. ред. Е. А. Цургановой и А. Е. Махова. М. : Intrada. 512 с. С. 297-301.

Чистякова, Н. А. (1966) Трактат «О возвышенном», его автор, время и содержание // О возвышенном / пер., статьи и примеч. Н. А. Чистяковой. М. ; $\Lambda$. : Наука. 149 с. С. 85-117.

Horatius, Flaccus. De ars poetica [Электронный ресурс] // Classical Latin Texts A Resource Prepared by The Packard Humanities Institute. URL: http://latin.packhum.org/loc/893/6/0\#0 (дата обращения: 20.05.2018).

Ovidii Nasonis, P. Metamorphoseon [Электронный ресурс] // Alpheios builds evidence-based, open-source software to support worldwide study of classical languages and literatures. URL: http:// repos-archive.alpheios.net/exist/rest/db/xq/alpheios-get-ref.xq?\&urn=urn:cts:latinLang:phi0959. phi006.alpheios-text-lat1:1.429-1.453 (дата обращения 20.05.2018).

Aата поступления: 12.09.2018 г.

\section{A. P. SUMAROKOV'S ESSAY “ON DISAGREEMENT"}

IN THE APRIL ISSUE OF THE MAGAZINE "HARDWORKING BEE": TEXT AND CONTEXT

\section{A. V. RAstyagaeV, Yu. V. SlOZHENIKINA \\ MOSCOW CITY UNIVERSITY, SAMARA BRANCH}

The article examines the semantic core of the April issue of the magazine "Hardworking Bee" the essay "On Disagreement" by A. P. Sumarokov. The urgency of research is determined by the fact that the magazine itself and each of its monthly books do not fall into the sphere of research interest of literary historians and journalism. The proposed research methodology is based on the synergy principle of several areas of the philological science of that time: the history of the Russian literature of the 18th century, the history of Russian journalism, and the history of the Russian literary language. 
This approach to the analysis, interpretation, and understanding of the magazine's metatext is meant to recreate a complete picture of the interaction of the author's intention and the readers' perception.

The article studies the meaning of the title "On Disagreement" as a strong position of the text, which implements the author's intention for dialogue with the contemporary reader. An attempt is made to restore the cultural context of this word usage in the works of Feofan Prokopovich, Peter I, V. K. Trediakovsky, and M. V. Lomonosov. In the written texts of the 18 th century, the word «disagreement» had different meanings. However, only Sumarokov puts this word in the title and, in addition to the communicative function, this word performs a meaning-making function.

The composition analysis of the rhetorical plot of Sumarokov's essay revealed the basic principle of its construction - to follow "natural simplicity". The thesis stated in the introduction about the true causes of disagreement between people - "dissimilarity of hearts" - is explained by the three examples of different subjects: love, property, and household. Further, the author's thought goes from the simple to the complex, and proceeds to the level of generalization in the context of world history. A number of the author's rhetorical questions in the conclusion of the article provoke the reader to give their own ethical assessment of the problem raised in the text.

The interpretation of the article's poetological plot consistently recreates its ancient Roman and late antique cultural contexts, and reveals the reception of the tradition of the early English Enlightenment as well.

The study of the text and context of one article in the April book of the magazine allows for a conclusion that Sumarokov's magazine is not only a new era in the development of the Russian journalism, but also a new word in poetics and hermeneutics, replacing rhetoric due to the efforts of the authors of "Hardworking Bee" in the middle of the 18th century.

Keywords: "Hardworking Bee"; A. P. Sumarokov; M. V. Lomonosov; rhetoric; poetics; Horace; Ovid; Pseudo-Longin; Addison; Steele; Russian literature of the 18th century; history of literature

\section{REFERENCES}

XV knig Prevrashchenij (1887), [Soch.] Publiya Ovidiya Nazona; V per. i s ob»yasn. A. Feta. Moscow, Publ. A.I. Mamontova i $\mathrm{K}^{\circ} .793$ p. (In Russ.).

Alekseeva, N. Yu. (2006) Literaturnaya polemika serediny XVIII veka o perevode stihov. XVIII vek, sb. st. i mat. vol. 24 / ed. by N. D. Kochetkova. St. Petersburg, Nauka Publ. 410 p. Pp. 15-34. (In Russ.).

Alekseeva, N. Yu. (2009) Kommentarii. Trediakovskij, V.K. Sochineniya i perevody kak stibami, tak $i$ prozoyu / Podgot. N. Yu. Alekseev. St. Petersburg, Nauka Publ. 667 p. Pp. 501-654. (In Russ.).

Chistyakova, N. A. (1966) Traktat «O vozvyshennom», ego avtor, vremya i soderzhanie. In: O vozvyshennom. Perevod, stat'i i primechaniya N. A. Chistyakovoj. Moscow; Leningrad, Nauka Publ, 149 p. Pp. 85-117. (In Russ.).

Curganova, E. A. (2008) Preodolenie zhanrovyh granic v literature rannego anglijskogo prosveshcheniya (zhurnaly Dzh. Addisona i R. Stila «Boltun», «Zritel'», «Opekun»). Literaturovedcheskij zburnal, no 23, pp. 170-195. (In Russ.).

Curganova, E. A. (2009) Dzhozef Addison o vkuse, «Udovol'stviyah voobrazheniya» i vozvyshennom. Literaturovedcheskij zhurnal, no. 25, pp. 137-149. (In Russ.).

Curganova, E. A. (2010) Anglijskaya poehtika. Rannee Prosveshchenie. Evropejskaya poebtika ot antichnosti do ehpobi Prosveshcheniya: EHnciklopedicheskij putevoditel'. Ed. by E. A. Curganova and A. E. Mahova. Moscow, Intrada Publ. 512 p. Pp. 297-301. (In Russ.).

Dal', V. I. (1995) Tolkovyj slovar' zhivogo velikorusskogo yazyka: in 4 vol. Moscow, TERRA Publ. Vol. 2. 779 p. (In Russ.).

Dal', V. I. (1995) Tolkovyj slovar' zhivogo velikorusskogo yazyka: in 4 vol. Moscow, TERRA Publ. Vol. 4. 683 p. (In Russ.).

Dzheparoskij, I. (2006) Pervyj arhetekst o vozvyshennom: Psevdo-Longin. Filologicheskie zamet$k i$, 2006. vol. 1. [online] Available at: http://philologicalstudies.org/index.php?option=com_content\&task=view\&id=86\&Itemid=48 (accessed 20.05.2018). (In Russ.). 
Goracij (1753) Pis'mo Goraciya Flakka o stibotvorstve k Pizonam. St. Petersburg, Publ., Pech. pri Imp. Akad. Nauk. 40 p. (In Russ.).

Goracij (1813) Poslanie k Pizonam, Bualo-Depreo Nikola. Nauka stibotvorstva v chetyrekb pesnyah stibami. Sochinenie g. Bualo-Depreo. Perevod grafa Hvostova. Izdanie vtoroe, s prilozheniem Goracieva k Pizonam poslaniya v podlinnike is rossijskim prozaicheskim onogo perevodom. St. Petersburg, Publ. V Morskoj tipografii, [6], VIII, 80, 53, [3] p. Pp. 1-53 (pag. 3-ya). (In Russ.).

Goracij (1853) Nauka poebzii, ili Poslanie k Pizonam: S pril. podlinnika, vved. i prim., sluzhashchimi k ob'yasn. orig. i per./ [Soch.] Kvint Goracij Flakk; Per. v stihah M. Dmitrieva. Moscow, Publ. tip. A. Semena. VIII, 90 p.

Goracij (1883). O poehticheskom iskusstve. K Pizonam. K. Goracij Flakk. Moscow, tip. M. P. Shchepkina, XVIII, 485 p. Pp. 445-485. (In Russ.).

Goracij (1970) K Pizonam. In: Goracij. Ody, Ehpody, Satiry, Poslaniya. Moscow, Publ. Hudozhestvennaya literature. 479 p. Pp. 383-395. (In Russ.).

Gukovskij, G. A. (1941) Sumarokov $i$ ego literaturno-obshchestvennoe okruzbenie, Istoriya russkoj literatury : in 10 vol. / gl. red.: P. I. Lebedev-Polyanskij, Moscow; Leningrad, AN SSSR Publ. Vol. 3, Literatura XVIII veka. Ch. 1. 424 p. Pp. 349-420. (In Russ.).

Horatius, Flaccus. De ars poetica [online], Classical Latin Texts A Resource Prepared by The Packard Humanities Institute. Available at: http://latin.packhum.org/loc/893/6/0\#0 (accessed 20.05.2018) (In Latin.).

Levin, Yu. D. (1967) Anglijskaya prosvetitel'skaya zhurnalistika v russkoj literature XVIII veka. Ebpoba Prosveshchenie. Iz istorii mezhdunarodnyb svyazej / ed. by M. P. Alekseev. Leningrad, Nauka, Publ. 364 p. Pp. 3-109. (In Russ.).

Lomonosov, M. V. (1957) Pis'mo Shuvalovu I. I., 1 noyabrya 1753 g. In: Lomonosov, M. V. Polnoe sobranie sochinenij. Moscow; Leningrad, AN SSSR Publ. Vol. 10: Sluzhebnye dokumenty. Pis'ma. 1734-1765 gg. 934 p. Pp. 495-497. (In Russ.).

Lomonosov, M. V. (1959) Slovo Pohval'noe blazhennyya pamyati Gosudaryu Imperatoru Petru Velikomu, govorennoe Aprelya 26 dnya 1755 goda. In: Lomonosov, M. V. Polnoe sobranie socbinenij. Moscow; Leningrad, 1950-1983. Vol. 8: Poehziya, oratorskaya proza, nadpisi, 1732-1764. 1279 p. Pp. 584-612. (In Russ.).

Lotman, Yu. M. (2002a) K sovremennomu ponyatiyu teksta. In: Lotman Yu. M. Istoriya i tipologiya russkoj kul'tury. St. Petersburg, Iskusstvo-SPB Publ. 768 p. Pp. 188-190. (In Russ.).

Lotman, Yu. M. (2002b) Semiotika kul'tury i ponyatie teksta. In: Lotman Yu. M. Istoriya i tipologiya russkoj kul’tury. St. Petersburg, Iskusstvo-SPB Publ. 768 p. Pp. 158-162. (In Russ.).

Mahov, A. E. (2010) Concordia discors. Evropejskaya poebtika ot antichnosti do ebpobi Prosveshcheniya: Ehnciklopedicheskij putevoditel', ed. by E. A. Curganova and A. E. Mahov. Moscow, Intrada Publ. 512 p. Pp. 324-327. (In Russ.).

O vozvyshennom (1966) / Transl. by N. A. Chistyakova. Moscow; Leningrad, Nauka Publ. 158 p. (In Russ.).

Pahsar'yan, N. T. (2010) Francuzskaya poehtika. Evropejskaya poebtika ot antichnosti do ebpobi Prosveshcheniya: Ebnciklopedicheskijputevoditel' / ed. by E. A. Curganova and A. E. Mahova. Moscow, Intrada Publ. 512 p. Pp. 178-192. (In Russ.).

Peskov, A. M. (1989) Bualo v russkoj literature XVIII pervoj treti XIX v. Moscow, MGU Publ. 176 p. (In Russ.).

Prokopovich, Feofan (1961) Slovo pohval'noe o batalii Poltavskoj: Skazannoe ... cherez chestnejshego otca, rektora Prokopovicha, iyunya v 27 den' 1717, Feofan (Prokopovich). Sochineniya, ed. by I. P. Eremina, Moscow; Leningrad, Publ. Akad. nauk SSSR. 502 p. Pp. 48-59. (In Russ.).

Ovidii Nasonis Pub. Metamorphoseon. Alpheios builds evidence-based, open-source software to support worldwide study of classical languages and literatures [online] Available at: http://reposarchive.alpheios.net/exist/rest/db/xq/alpheios-get-ref.xq?\&urn=urn:cts:latinLang:phi0959. phi006.alpheios-text-lat1:1.429-1.453 (accessed 20.05.2018) (In Latin.).

Ovidij Nazon Publij (1977) Metamorfozy / Transl. by S. V. Shervinskii. Moscow, Hudozhestvennaya literature Publ., 430 p. (In Russ.). 

Russ.).

Rak, V. D. (2008) Stat'i o literature VIII veka. St. Petersburg, Pushkinskij dom Publ. 640 p. (In

Reglament ili ustav glavnogo magistrata (1937). Reformy Petra I. Sbornik dokumentov / comp. by V. I. Lebedev. Moscow, Gos. soc.-ehk. Publ. 376 p. Pp. 187-206. (In Russ.).

Serman, I. Z. (2002) Neizdannyj konspekt M. V. Lomonosova «Traktata o vozvyshennom» PsevdoLongina v perevode N. Bualo. In: XVIII vek, sb. st. i mat. / ed. by N. D. Kochetkova. St. Petersburg, Nauka Publ. Vol. 22. Pp. 333-346. (In Russ.).

Slovar' russkogo yazyka veka XVIII veka (2015), ed. by A. A. Alekseev. St. Petersburg, Nauka Publ. Vol. 21. Podoba - Pomoshchnyj. 457 p. (In Russ.).

Staroslavyanskij slovar' (po rukopisyam X-XI vekov) (1999), ed. by R. M. Cejtlin, R. Vecherki and Eh. Blagova. Moscow, Russkij yazyk Publ. 842 p. (In Russ.).

Trediakovskij, V. K. (2009) Socbineniya i perevody kak stibami, tak i prozoyu. St. Petersburg, Nauka Publ. 667 p. (In Russ.).

Submission date: 12.09 .2018$.

Растягаев Андрей Викторович - доктор филологических наук, профессор, заведующий кафедрой филологии и массовых коммуникаций Самарского филиала Московского городского педагогического университета. Адрес: 443081, Россия, г. Самара, ул. Стара-Загора, А. 76. Тел.: +7 (846) 205-76-45. Эл. адрес: avr67@yandex.ru

Сложеникина Юлия Владимировна - доктор филологических наук, профессор кафедры филологии и массовых коммуникаций, декан филологического факультета Самарского филиала Московского городского педагогического университета. Адрес: 443081, Россия, г. Самара, ул. Стара-Загора, д. 76. Тел.: +7 (846) 205-76-45. Эл. адрес: goldword@mail.ru

Rastyagaev Andrey Viktorovich, Doctor of Philology, Head, Department of Philology and Mass Communications, Moscow City University, Samara Branch. Postal address: 76, Stara-Zagora St., Samara, Russian Federation, 443081. Tel.: +7 (846) 205-76-45. E-mail: avr67@yandex.ru

Slozhenikina Yulia Vladimirovna, Doctor of Philology, Professor, Department of Philology and Mass Communications, Moscow City University, Samara Branch. Postal address: 76, Stara-Zagora St., Samara, Russian Federation, 443081. Tel.: +7 (846) 205-76-45. E-mail: goldword@mail.ru

DOI 10.17805/zpu.2018.4.15

\title{
Сборник японских стихотворений «Сюгёкусю» (1346): автор и составитель
}

\author{
В. А. ФЕДЯНИНА \\ МОСКОВСКИЙ ГОРОДСКОЙ ПЕДАГОГИЧЕСКИЙ УНИВЕРСИТЕТ
}

Данная статья излагает некоторые из результатов исследования, посвященного изучению литературного и философского наследия Дзиэна (1155-1225), японского монаха буддийской школы Тэндай. В работе анализируется роль принца-монаха Сонъэна (1298-1356) в сохранении стихотворений Дзиэна, известного поэта периода расцвета классической японской поэзии. В 1346 г. Сонъэн собрал около 6000 тысяч японских стихотворений «вака» Дзиэна в сборник «Сюгёкусю» (“Собрание драгоценных жемчужин»). Настоящее исследование, основанное на текстологическом анализе, прослеживает историю составления «Сюгёкусю», памятника средневековой культуры, важного для реконструкции истории японской поэзии и японской буддийской мысли; раскрывает значи- 